\title{
Technology-Based Startups Fail to Face the Impact of Covid-19
}

\author{
Aldrich Ilyas $^{1}$, Suryo Hadiyono ${ }^{2}$, Amir Hamzah ${ }^{3}$, Rizq Atika Maso ${ }^{4}$ \\ \{aldrich.ilyas@bppt.go.id ${ }^{1}$, suryo.hadiyono@bppt.go.id ${ }^{2}$, amir.hamzah@bppt.go.id ${ }^{3}$, \\ rizq.atika@bppt.go.id $\left.{ }^{4}\right\}$
}

Technology Based Business Incubator, Agency for the Assessment and Application of Technology Puspiptek area, Building 720, Muncul, Serpong District, South Tangerang City, Banten 15314 (+62 21) 75791384 / 7560101, info-bit@ bppt.go.id ${ }^{1234}$

\begin{abstract}
Covid-19 pandemic give out impact on health, economy, social and politic field in all country around the world including Indonesia at this time. In economics field, many business sector faced deceleration due Covid-19 viruses. Startup based on technology (PPBT) is one entity of the businesses affected Covid-19 on economic fields. This study aims to determine Covid-19 pandemic to PPBT sustainability and cause of their failure. This type of research is descriptive, data collection methods using open questionnaire. The number of respondent was 151 startup based on technology result of incubation from incorporated business incubator in Indonesian Business Incubator Association (AIBI). The value rate of discontinue startup based on technology in the Energy field 57\%, Manufacture 29\%, Transportation 25\%. The most problem faced PPBT during pandemic is declining sales, impeded production process, impeded product distribution, difficulty in obtaining raw materials. The conclusion of this study is that PPBT in faced Covid-19 pandemic to experience failure potentially if they are not resolve the main problems that is declining sales, impeded production process, and impeded product distribution. Furthermore, the data from this research used to policy analyzing and business management strategies for startup based on technology to give enhancement and business development sustainability well.
\end{abstract}

Keywords: Business incubator, Startup based on technology, PPBT, Covid-19 pandemic. 


\section{Introduction}

Covid-19 virus is still an evident threat for countries around the world. According to $\mathrm{WHO}$, increasing number of new cases of covid-19 continue to raise. By July 7 2020, 11,500,302 recorded cases spread out at 216 countries. The highest number of cases are found in United State, Brazil, India, Russia, and Peru [1]. Indonesia recorded 66,226 confirmed cases, 3,309 death, and 30,785 recovery [2].

Despite the raising of recovering number, the emergence of new cases due to Covid-19 spread is also escalating thus effecting the state of Indonesian economic. Based on Statistic Indonesia (BPS) report, Indonesia's economy 2020 Quarter only grew by $2.97 \%$ slowing down compare to $5.07 \%$ at the same quarter in 2019 [6]. Meanwhile on last quarter, Indonesia's economic growth 2020 quarter 1 (q-to-q) experiencing a contraction $2.41 \%$ Covid-19 pandemic not only causing Indonesia's economic slowdown, but also affecting the condition of the Start-ups from incubators. This paper will assess the impact of economic slowdown as a result of Covid-19 on Start-up's business condition

\section{Method}

This research used quantitative method with open question data collection tool. Open question is a questioner that does not offer answer to the question provided thus responded has the freedom to answer the question [10].

The research's stage began at formulating question attribute that related to start-up's business condition on Covid-19 pandemic, the question attribute in the questioner were:

1. What is your Start-up name?

2. What is the name of incubator that assisted your business?

3. What is your start-up legal status? Is it incorporated or unincorporated?

4. When does your Start-up graduate?

5. What is your startup business field?

6. How is your startup condition on Covid-19 pandemic, still running or stop?

7. When does your Start-up business stop running?

8. What is the reason of your Start-up stop running?

9. What is the obstacle that caused your business stop running?

10. What is your expectation of incubator's role as Start-up business facilitator? 
The respondents were 151 Start-up from business incubators that are members of Indonesia Business Incubator Association (AIBI). Data analysis method used was descriptive qualitative that is research technic which describes and explains collected data by observing and recording as many as possible researched aspect so that overall picture of real condition can be obtained. The step by step of qualitative data analysis in this research are: data collection, data reduction, data presentation, and drawing conclusion.

\section{Result}

Data analysis in this descriptive qualitative research was done while the data was being collected and after the data was compiled

\section{Data Collection}

The data was collected by researcher through data form of questionnaire result's spreadsheet that was distributed to the 151 incubatee respondent from business incubators that are members of Indonesia Business Incubator Association (AIBI). Then the data form was grouped according to the questions in the researched that has been prepared.

\section{a) Incubator}

These are the incubators that have incubated the 151 Startups respondents and assisted their business: 


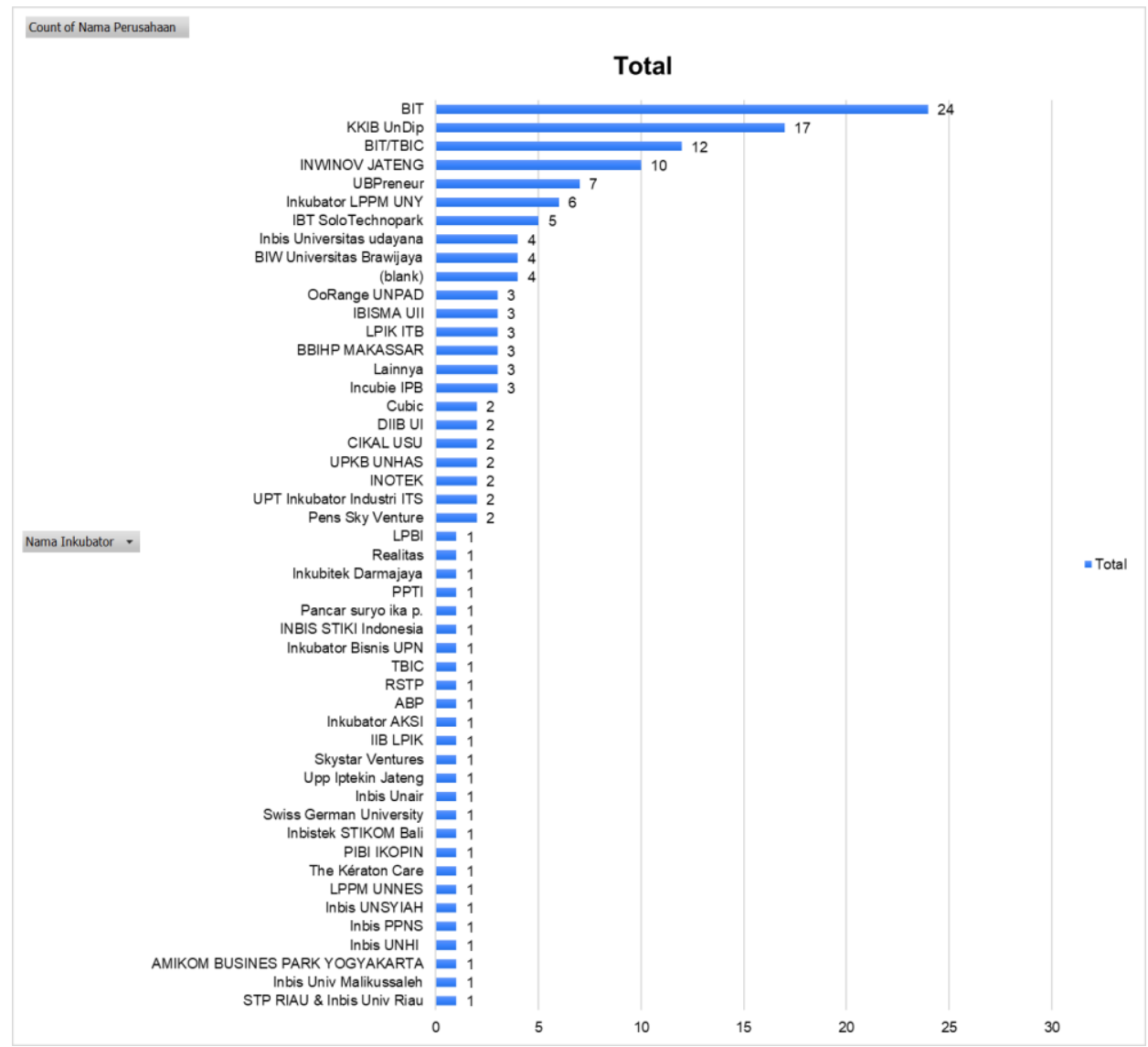

Figure 1. Business Incubators that Helps Startups to Develop

\section{b) Legal Entity}

From 151 Startup respondents, there are 120 incorporated Startups (79\%) both are limited company and limited partnership, and 31 (21\%) Startup are unincorporated.

\section{c) Graduation year from incubation program}

There are 78 graduate startup graduate in 2019 from incubation program, where it also the most year have incubators graduated the Start-up. 


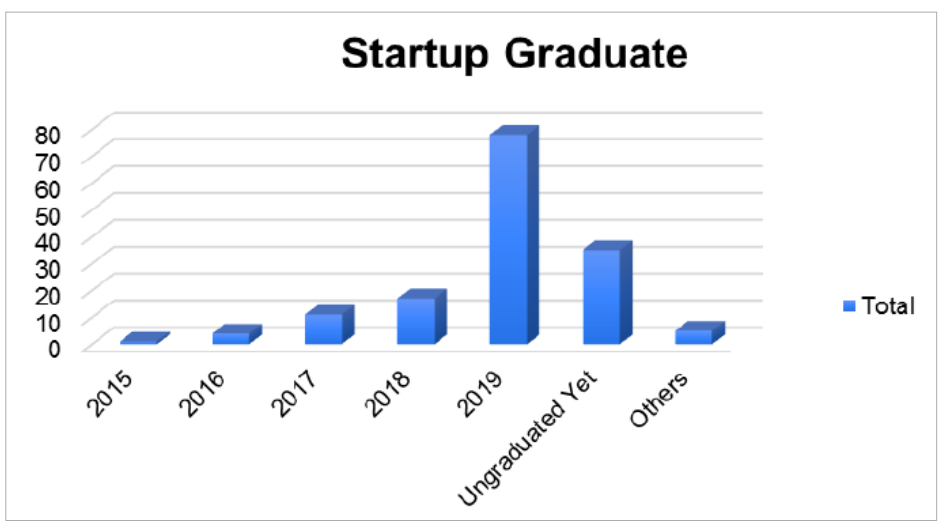

Figure 2. Total Graduated Startup from Incubation Process in Incubators

\section{d) Startup Business field}

In the questionnaire, the researcher divided the categories into 6 fields. They were:
1. Energy
2. Information Technology
3. Health and medicine
4. Manufacture
5. Agriculture and food security
6. Transportation

From 151 Respondents, most companies were from agriculture and food security field with 49 Startup (32\%) followed by Information Technology with 46 Startup (30\%).

Table 1. Startup's Business Fields

\begin{tabular}{llc}
\hline No & Business Fields & Amount \\
\hline 1 & Agriculture and food security & 49 \\
2 & Information Technology & 46 \\
3 & Manufacture & 24 \\
4 & Health and medicine & 21 \\
5 & Energy & 7 \\
\hline
\end{tabular}


The complete percentage of the business field can be shown on graphic below:

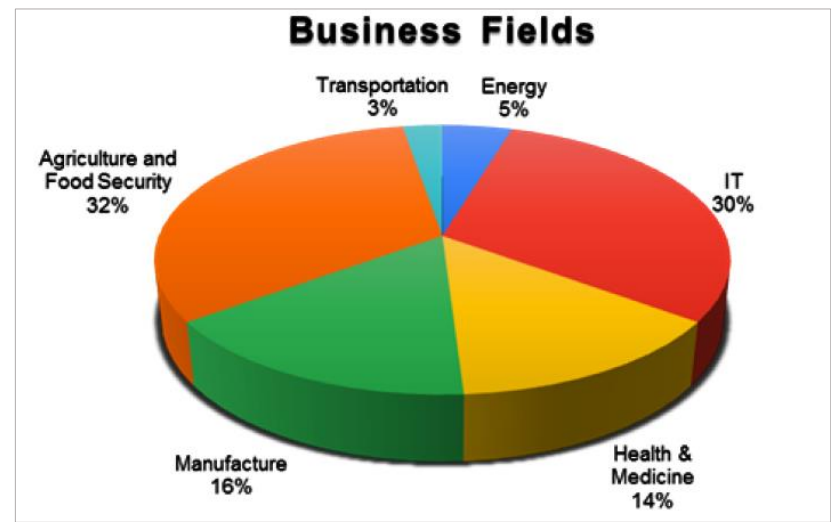

Figure 3. Startup Business Fields

\section{Data Reduction}

In this stage, the activity was compiling, choosing main points, focusing on the important regards from the questionnaire results. In the questionnaire that has been distributed to the startups contained several things that were important for the researchers, such as the impact of Covid-19 pandemic in Indonesia to startup business condition. Within this assessment, the main things would be addressed were the startup failure due to Covid-19 Pandemic in Indonesia, meaning this research's object specified to the Startup that could not survive dealing with the pandemic.

From 151 Startups that have filled the questionnaire, there were 120 (79\%) startups that still running in this Covid-19 pandemic and there were 31 (21\%) Startups that stopped running.

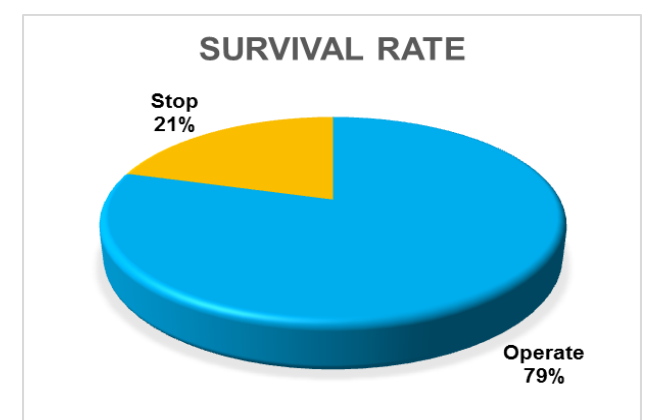

Figure 4. Startup's Survival Rate during the Covid-19 Pandemic 
Hereafter, from $21 \%$ Startup that was not operating anymore, the cause of Startup from incubation program's failures to Covid-19 pandemic would be investigated further

\section{Data Presentation}

The stage of data presentation stage is an activity to pull the information from the data that has been reduced with the intention of simplify drawing the conclusion.

\section{a) Startup affected by Covid-19 pandemic}

The 151 respondents were Startups from business incubators that are members of Indonesia Business Incubator Association (AIBI).

The result shown that the startup which stopped running in this Covid-19 era were 31 Startups or $21 \%$.

The most amount of Startup that collapse due to Covid-19 pandemic came from IT field with 11 Startups (35\%) and then in chronological order: manufacture 7 Startups (23\%), agriculture and food security 7 Startups (23\%), Energy 4 startups (13\%), health and medicine 1 startup (3\%), and transportation 1 startup $(3 \%)$

Table 2. Startup that was not operating due to Covid-19

\begin{tabular}{llcc}
\hline No & Startup field & Amount & Percentage \\
\hline 1 & Information Technology & 11 & $35 \%$ \\
2 & Manufacture & 7 & $23 \%$ \\
3 & Agriculture and food security & 7 & $23 \%$ \\
4 & Energy & 4 & $13 \%$ \\
5 & Health and medicine & 1 & $3 \%$ \\
6 & Transportation & 1 & $3 \%$ \\
\hline
\end{tabular}

Based on data from questionnaires that were obtained by researcher, The start of startup stopped running was happened in the time span of January 2020 to April 2020 wherein that time the Covid-19 began to affect the world and eventually spread in Indonesia. These are the startups that stopped running due to Covid-19 pandemic: 
Table 3. Startup's stopped running

\begin{tabular}{|c|c|c|c|c|}
\hline No & \multirow{2}{*}{\multicolumn{2}{|c|}{$\begin{array}{l}\text { Startup Name } \\
\text { PT. Mobisa His Teknologi }\end{array}$}} & No & Startup Name \\
\hline 1 & & & 17 & $\begin{array}{l}\text { CV Mandike } \\
\text { Instruments }\end{array}$ \\
\hline 2 & $\begin{array}{l}\text { PT. Indocor } \\
\text { Teknologi }\end{array}$ & Rekayasa & 18 & $\begin{array}{l}\text { PT. Erdelapan Steam } \\
\text { Otomatika }\end{array}$ \\
\hline 3 & $\begin{array}{l}\text { International } \\
\text { Network }\end{array}$ & Global & 19 & $\begin{array}{l}\text { PT. Sekatup Sari } \\
\text { Indonesia }\end{array}$ \\
\hline 4 & $\begin{array}{l}\text { Hyperion } \\
\text { Indonesia }\end{array}$ & Teknologi & 20 & Jemarietnik.id \\
\hline 5 & Geofast & & 21 & $\begin{array}{l}\text { PT. Precision } \\
\text { Agriculture Indonesia }\end{array}$ \\
\hline 6 & Warkop Pak Tan & & 22 & Jaya Lestari Tehnik \\
\hline 7 & Tourin Indonesia & & 23 & $\begin{array}{l}\text { PT. Karunia Kautsar } \\
\text { Perdana }\end{array}$ \\
\hline 8 & CV. Phico Tekno & ogi & 24 & $\begin{array}{l}\text { Gunungsari } \\
\text { Wiarsadana }\end{array}$ \\
\hline No & Startup Name & & No & Startup Name \\
\hline 9 & CV. Ganesha Ecc & energy & 25 & $\begin{array}{l}\text { CV. Melzie Marine } \\
\text { Mandiri }\end{array}$ \\
\hline 10 & CV. Eustore & & 26 & Phy.co \\
\hline 11 & Dipo rental & & 27 & $\begin{array}{l}\text { PT. Yeda Presisi } \\
\text { Engineering }\end{array}$ \\
\hline 12 & Nothing.id & & 28 & CV. Arkanfood \\
\hline 13 & Indonesia Tour $C$ & aide & 29 & CV. Agro Herba \\
\hline 14 & Tabler & & 30 & $\begin{array}{l}\text { CV. Sangko Usaha } \\
\text { Baru }\end{array}$ \\
\hline $\begin{array}{l}15 \\
16\end{array}$ & $\begin{array}{l}\text { CV. Abpan Mult } \\
\text { PT. Gotong Roy } \\
\text { Bangsa }\end{array}$ & $\begin{array}{l}\text { Kreasindo } \\
\text { ng Bangun }\end{array}$ & 31 & CV. GUB \\
\hline
\end{tabular}

\section{b) The reason of Startup's Business Stop Running in Covid-19 pandemic era}

Researcher provided choice of reasons why the startup stop operating in the covid-19 pandemic era. The reasons can be chosen by the startup as cause of failure. There are three reasons that was given by the researcher to the startup, the reasons were made by considering general condition that happened to the companies which stopped running. The reasons are:

a) No market demands

b) Unable to produce

c) Mutual health 
From 31 startups respondents that stop running and filled the questionnaire the cause of Startup's business failure due to Covid-19 pandemic most chose no market as the answer with 18 startups (58\%) and then chose mutual health was chosen by 12 startup (39\%) and least chosen answer was unable to produce by 1 startup (3\%)

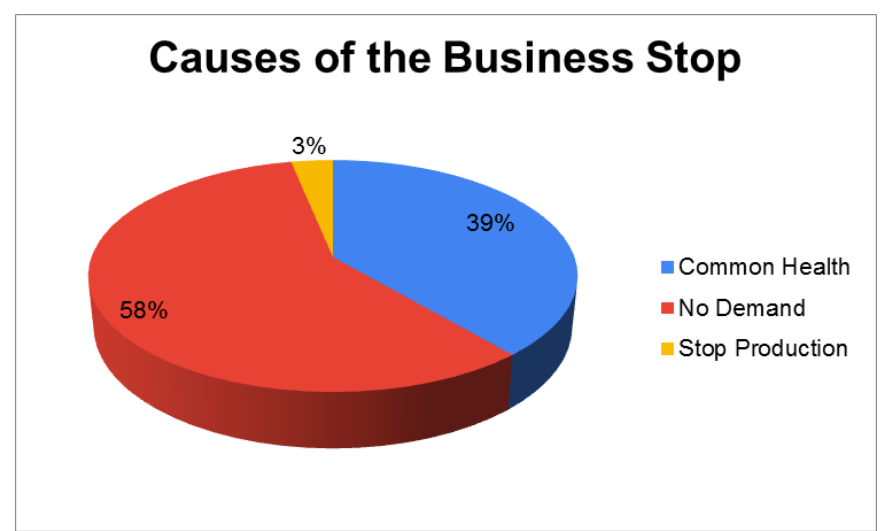

Figure 5. The Causes of Startup Business Stop During Covid-19 Pandemic

\section{c) The Obstacles Faced by Startups on Covid-19 Pandemic}

Alongside to the researcher provided the reasons that made startup's business stopped running on covid-19 pandemic, researcher also provided multiple choices on the obstacles faced by the startup on the questionnaire, the obstacle are:

1. Obstacle on Raw material

2. Obstacle on Production process

3. Obstacle on distribution process

4. Legal, product certification, and permit processing

5. Selling product or service

In spite of the obstacles provided by the researcher, respondents can also add more obstacle the faced exclusively by the startup on dealing with this pandemic. The result of the questionnaire was the obstacles faced by the startup so that their business stop running was selling $35 \%$, obstacle on production process was $26 \%$ and distribution process was $21 \%$ whereas obstacle on raw material was $11 \%$ and permit process, legal and certification was $7 \%$.

The results of the questionnaire also found that Startup who stopped operating have business barriers on sales were selected 25 times by Startup, obstacles in the production process were selected 19 times by Startup, barriers to distribution were chosen 15 times by Startup, barriers to raw materials were 
chosen 8 times by Startup and barriers to obtaining a legality permit or certification is chosen 5 times by Startup.

Table 4. Obstacles Faced by Startups during the Covid-19 Pandemic

\begin{tabular}{llcc}
\hline No & Obstacles & Total & Percentage \\
\hline 1 & Barriers to selling products or services & 25 & $35 \%$ \\
2 & Obstacles to the Production Process & 19 & $26 \%$ \\
3 & Barriers to the distribution process & 15 & $21 \%$ \\
4 & Obstacles that occur due to raw materials & 8 & $11 \%$ \\
5 & Obstacles to obtaining permits, both product & 5 & $7 \%$ \\
& certification and company legality permits & \\
\hline
\end{tabular}

\section{d) Startup Expectations for the Incubator Institution as a Startup Business Partner}

From startups that stopped operating, they had high expectation for the incubator. Because according to them the role of the incubator is very important in business assistance for startup companies to develop through the incubation process. Expectations conveyed by Startup include,

1. The incubator institutes carrying out online marketing training for Startups

2. Providing investment access to Startup

3. Help provide additional capital

4. The incubator institutes hold online mentorship every Saturday and Sunday

5. Provide an extension of the incubation process than the normal condition

6. Issue preventive measures periodically for Startups in the face of the Covid-19 pandemic

7. Providing services in the form of training / tips in order to anticipate financial management and business management amid the Covid-19 pandemic and the current economic crisis

8. Give the information on startup processes and business model solution solutions

9. Provide a post Covid-19 pandemic strategy to Startup

10. Provides access to investment to Startup

11. Services in the case of online applications for e-commerce sales and inter-island product distribution through online applications that are integrated with similar business fields. 


\section{Conclusion}

From this study it can be concluded that of the 151 Startups who had filled out the questionnaire, there were 120 (79\%) Startups that were still operating in the Covid-19 pandemic and there were 31 (21\%) startups stop operating. Startups in the IT business sector experienced the largest business failures by 11 Startups (35\%) failed to face the Covid-19 pandemic, then successively in the Manufacturing business sector as many as 7 Startups (23\%), Agriculture and Food Security as many as 7 Startups (23\%), Energy as much as 4 Startups $(13 \%)$, Health and Medicine as much as 1 Startup (3\%), and Transportation as much as 1 Startup (3\%).

From 31 Startups that stopped operating that answered the questionnaire that caused the failure of the Startup business during the Covid-19 pandemic, it was found that the reason there was no market demand occupies the most choices of Startups with 18 (58\%), then the Startup chose common health issues so that closing the business was chosen by 12 Startups (39\%), and could not producing was selected by 1 Startup (3\%).

The results of the questionnaire also found that Startup business stopped operating having obstacles in sales by $35 \%$, obstacles in the production process by $26 \%$, obstacles in distribution by $21 \%$, obstacles in raw materials by $11 \%$ and obstacles in obtaining legality or certification permits by $7 \%$.

From the questionnaire also found that Startup business stopped operating having barriers on sales were selected 25 times by Startup, obstacles in the production process were selected 19 times by Startup, barriers to distribution were chosen 15 times by Startup, barriers to raw materials were chosen 8 times by Startup and barriers to obtaining a legality permit or certification is chosen 5 times by Startup.

\section{Recommendation}

For Startup, this research contributes in the field of business management in particular business preparation strategies in the face of the Covid-19 pandemic in the future which will potentially fail if it cannot overcome the main problem of declining sales, constrained production processes and constrained product distribution. Furthermore, for future research the data from this research are used further in the formulation of policies and business management strategies for technology-based startups that can provide improvement and development of business sustainability well. 


\section{References}

[1] Government Regulation No 21 of 2020. Large-Scale Social Restrictions in Order to Accelerate Handling of Corona Virus Disease 2019 (Covid-19). March $31^{\text {st }} 2020$. Ministry of Law and Human Rights of the Republic of Indonesia. Jakarta

[2] Regulation of the Head of the Technology Incubator Center No. 1 of 2019. General Provisions and Guidelines for the Implementation of Technology Business Incubation Services. Technology Incubator Center. Jakarta

[3] Ministry of Research, Innovation, Technology and Higher Education of the Republic of Indonesia. 2017. National Research Master Plan for 2017-2045. Ministry of Research, Innovation, Technology and Higher Education. Jakarta

[4] Acceleration Handling Task of Covid-19. 2020. Covid-19 Distribution Data Dashboard. https://covid19.go.id/ . May $7^{\text {th }} 2020$ (19.00)

[5] WHO. 2020. WHO Coronavirus Disease (Covid-19) Dashboard. https://covid19.who.int/. July $7^{\text {th }} 2020(19.00)$

[6] BPS-statistics Indonesia. 2019. Executive Summary of Result of Establishment Data Collection. Economic Census 2016-Continued.

[7] Hamdani, et al. 2013. Technology based Incubators Business Process. BIT-BPPT. Jakarta

[8] Juaningsih, Imas Novita. Analysis of lay-off policies for workers during the Covid-19 pandemic in Indonesia. Adalah: Law and Justice Bulletin. Vol 4 No 1.

[9] Rangkuti, Freddy. 2013. Analisis SWOT Teknik Membedah Kasus Bisnis. Gramedia. Jakarta

[10] Walgito, Bimo. 1999. Pengantar Psikologi Umum. Yogyakarta: Andi offset. 


\section{Attachment}

a) Startup Name

These are the Startups that have complete the questionnaire:

Table 5. Startup's Name

\begin{tabular}{|c|c|c|c|}
\hline No & Startup Name & No & Startup Name \\
\hline 1 & CV. GUB & 79 & Beyond Childhood \\
\hline 2 & CV. Diana Hermawati Indonesia & 80 & PT. Mertani Inovasi Group \\
\hline 3 & PT. Nanotech Herbal Indonesia & 81 & CV. Gentra Dewantara Persada \\
\hline 4 & PT. Powertech Nano Industri & 82 & Kiddo.id \\
\hline 5 & PT. Mobisa His Teknologi & 83 & Hyperion Teknologi Indonesia \\
\hline 6 & Agrotek Pintar Nusantara, PT. & 84 & CV. Narendra Food \\
\hline 7 & PT. Hebat Inovasi Indonesia & 85 & PT. KMTek \\
\hline 8 & CV. Indigo Biru Baru & 86 & Sakti Builder Internasional \\
\hline 9 & PT.Evia Maju Bersama & 87 & Green Well Indonesia \\
\hline 10 & PT. Indocor Rekayasa Teknologi & 88 & Talkabot \\
\hline 11 & PT. Biocon Natural Indonesia & 89 & Morifa \\
\hline 12 & PT. Pustek & 90 & Geofast \\
\hline 13 & International Global Network & 91 & CV. Catalyst Agro Inovasi \\
\hline 14 & PT. Neoalgae Indonesia Makmur & 92 & PT.Sembalun Jaya Agro \\
\hline 15 & Little Momo & 93 & Exofish \\
\hline 16 & PT. Adhiguna Jaya Laboratorium & 94 & Telaga Filter Air Minum \\
\hline 17 & PT. Duta Mandiri Harapan Industri & 95 & Warkop Pak Tani 88 \\
\hline 18 & PT. Cipta Mikro Material & 96 & Safewalk Petrok \\
\hline 19 & PT. Master Solusi Indonesia & 97 & CV. Haryo Industri \\
\hline 20 & PT. Natural Molekuler Universal & 98 & PT. Yooreka Media Kreasi \\
\hline 21 & PT.Bangun Mesin Sejahtera & 99 & Ruang Bahasa \\
\hline 22 & PT. Pico biru & 100 & Tourin Indonesia \\
\hline 23 & Biomagg & 101 & PT Ecodoe Widya Candia Internasional \\
\hline 24 & PT. Valensi Cahaya Persada & 102 & CV. Allisha Foods \\
\hline 25 & PT. Wiforgo Surya Solusi & 103 & CV. Sangko Usaha Baru \\
\hline 26 & PT. Indobits Digital Raya & 104 & CV. Ayo Nandur \\
\hline 27 & CV. Mekar Djaya Harum & 105 & CV. Phico Teknologi \\
\hline 28 & CV. Algorista Robotics & 106 & PT. Sang Juara Nusantara, Sojavu \\
\hline 29 & SQF Sawangan & 107 & CV.RWIN Development \\
\hline 30 & PT. Global Indotech Madani & 108 & Yuam Roasted Coffee \\
\hline 31 & CV. Buntoro Karto Tani & 109 & CV. Seleksi Alam Muria \\
\hline 32 & PT. Algaepark Indonesia Mandiri & 110 & $\begin{array}{l}\text { CV Kelola Anugerah Bahari } \\
\text { (Indofishery.id) }\end{array}$ \\
\hline 33 & PT. Microtec Sukses Indonesia & 111 & CV. Ganesha Ecoenergy \\
\hline 34 & PT. Dayamix Bumi Indonesia & 112 & Vantis ( Guava Ron) \\
\hline 35 & PT. Zara Propertifarm Indonesia & 113 & Hydrogarden \\
\hline 36 & Halofina & 114 & CV. Agra Aksata \\
\hline 37 & CV. Progresif & 115 & CV. Eustore \\
\hline
\end{tabular}




\begin{tabular}{|c|c|c|c|}
\hline No & Startup Name & No & Startup Name \\
\hline 38 & Criquet Food & 116 & Dipo Rental \\
\hline 39 & Rizs florist & 117 & CV. Mandike Instruments \\
\hline 40 & Agradaya & 118 & Rolic \\
\hline 41 & Compac Motorcycle & 119 & Ruang Bahasa \\
\hline 42 & Rumah Mocaf & 120 & PT. Arme Studio Indonesia \\
\hline 43 & DigiTiket & 121 & AW Food Yogyakarta \\
\hline 44 & Nothing.id & 122 & CV. Berkreasi Multitech \\
\hline 45 & Equilibrium & 123 & $\begin{array}{c}\text { Tech Prom Lab (PT. Teknologi Kanggo } \\
\text { Nusantara Bagja) }\end{array}$ \\
\hline 46 & Filantrop.id & 124 & CV. Cipta Utama Karya Mandiri \\
\hline 47 & PT. Dhrei Danadhipa Ghanapati & 125 & Triarsa Plastika Indonesia \\
\hline 48 & PT. Miun Sinergi Nusantara & 126 & SyarQ \\
\hline 49 & CV.Mantu Sedana & 127 & CV. Digital Lontar Nusantara \\
\hline 50 & Sukagrafis & 128 & ALGIST / PT. Putra Medikaltek Indonesia \\
\hline 51 & PT. Generasi Karya Indonesia & 129 & PT. Erdelapan Steam Otomatika \\
\hline 52 & CV. Sumi Inotech & 130 & PT Rayeuk Aceh Utama \\
\hline 53 & Indonesia Tour Guide & 131 & CV. Hanum Shafira \\
\hline 54 & CV.Mantu Sedana & 132 & Raya Internasional Kosmetik \\
\hline 55 & CV. Sirobo Indonesia & 133 & PT. Sekatup Sari Indonesia \\
\hline 56 & PT. Fugha Pratama Mandiri & 134 & Jemarietnik.id \\
\hline 57 & Tabler & 135 & PT. Precision Agriculture Indonesia \\
\hline 58 & CV. Abpan Multi Kreasindo & 136 & PT. Laporanku Usaha Indonesia \\
\hline 59 & CV.Siwarak Sejahtera Sentosa Food & 137 & Jaya Lestari Tehnik \\
\hline 60 & Teman Belajar & 138 & $\begin{array}{c}\text { Jalan Cisaranten Kulon I No. } 8 \text { RT 06/05. } \\
\text { Bandung, Jawa Barat }\end{array}$ \\
\hline 61 & CV. Moving Serving Rising & 139 & PT. Karunia Kautsar Perdana \\
\hline 62 & Rumah Mocaf & 140 & Gunungsari Wiarsadana \\
\hline 63 & PT. Gotong Royong Bangun Bangsa & 141 & SUTIKE / CV. Surya Tirta Kencana Putra \\
\hline 64 & CV. Vigory Indonesia & 142 & CV. Melzie Marine Mandri \\
\hline 65 & SPD Speedometer & 143 & Phy.co \\
\hline 66 & CV. Dua Akar Food & 144 & PT. Yeda Presisi Engineering \\
\hline 67 & Putrimas Collection & 145 & CV. Arkanfood \\
\hline 68 & CV.Pak Ombak Djaya & 146 & CV. Agro Herbal \\
\hline 69 & PT. Astro Teknologi Internasional & 147 & CV. PLCD Edukasi Nusantara \\
\hline 70 & PT. Tesla Daya Elektrika & 148 & CV. Sangko Usaha Baru \\
\hline 71 & CV. Tekila Herbal Inovasi & 149 & PT. Wahana Gerak Indonesia \\
\hline 72 & CV. Amorina Kirana Adiwarna & 150 & PT. Alfath Teknologi Kreatif \\
\hline 73 & CV.Sari amertha & 151 & PT. Fastrobotic Insan Teknologi \\
\hline 74 & Jetschool & & \\
\hline 75 & Restoku & & \\
\hline 76 & CV. Galang Samudra Jaya & & \\
\hline 77 & Pijar Career Center & & \\
\hline 78 & PT. Kedata Indonesia Digital & & \\
\hline
\end{tabular}

